\title{
Biodegradation of aliphatic hydrocarbon by indigenous fungi isolated from used motor oil contaminated sites
}

\author{
A. Husaini · H. A. Roslan · K. S. Y. Hii • \\ C. H. Ang
}

Received: 8 April 2008/Accepted: 1 July 2008/Published online: 22 July 2008

(C) Springer Science+Business Media B.V. 2008

\begin{abstract}
Eighteen indigenous fungal isolates has been successfully isolated from samples of used motor oil, top five centimetres of soil and drainage water contaminated with used motor oil. All of the pure fungal isolates obtained were identified, characterized and subjected to preliminary screening by evaluating the average growth rate of each fungal isolates on minimal media containing $1 \%(\mathrm{v} / \mathrm{v})$ used motor oil. Trichoderma asperellum strain TUB F-1067 (SA4), Trichoderma asperellum strain Tr48 (SA5), Trichoderma asperellum strain TUB F-756 (SA6), Penicillium species (P1), and Aspergillus species (P9) were further selected for their hydrocarbon biodegradation potential. Among these five fungal isolates selected, P1 strain presented a significant degree of degradation by degrading almost all of the $n$-alkanes ( $n-\mathrm{C}-{ }_{15}$ to $n-\mathrm{C}-{ }_{23}$ range) present in the used motor oil, thus of greater potential in degrading the aliphatic hydrocarbon compounds of used motor oil.
\end{abstract}

Keywords Biodegradation - Indigenous fungi ·

Aliphatic hydrocarbon - Gas chromatographic analysis

$\begin{array}{ll}\text { Abbreviations } \\ \text { PAHs } & \text { Polyaromatic hydrocarbons } \\ \text { MEA } & \text { Malt extract agar } \\ \text { GC-FID } & \text { Gas Chromatography Flame Ionization Detector } \\ \text { BSA } & \text { Bovine serum albumin } \\ \text { g } & \text { Gram }\end{array}$

The authors would like to certify that the work have not been sent/ considered to be published in other journals.

A. Husaini $(\bowtie) \cdot$ H. A. Roslan · K. S. Y. Hii · C. H. Ang Department of Molecular Biology, Faculty of Resource Science and Technology, Universiti Malaysia Sarawak, 94300 Kota Samarahan, Sarawak, Malaysia

e-mail: haahmad@frst.unimas.my $\begin{array}{ll}\mathrm{ml} & \text { Mililiter } \\ \mathrm{rpm} & \text { Rotation per minute }\end{array}$

\section{Introduction}

Environmental pollution with petroleum and petrochemical products has attracted much attention in recent decades. The presence of various kinds of automobiles and machinery vehicles has caused an increase in the use of motor oil. Oil spillages into the environment have become one of the major problems. Spillages of used motor oils such as diesels or jet fuels contaminate our natural environment with hydrocarbon. The hydrocarbons spread horizontally on the ground-water surface and partition into groundwater, soil pore space air and to the surfaces of soil particles (Plohl et al. 2002). Hydrocarbon contamination of the air, soil, freshwater (surface water and groundwater) especially by Polycyclic Aromatic Hydrocarbon (PAHs) has drawn public concerns because many PAHs are toxic, mutagenic, and carcinogenic (Bumpus 1989; Clemente et al. 2001; Cerniglia and Sutherland 2001).

The use of fungi as a method of bioremediation provides an option to clean up environmental pollutants. Bioremediation using fungi have drawn little attention in the past two decades since most of the bioremediation researches focused mainly on the use of bacteria. Nevertheless, recently fungi have received considerable attention for their bioremediation potential that is attributed to the enzymes they produced that are involved in lignin breakdown which degrade a wide range of recalcitrant pollutants such as polyaromatic hydrocarbons, chlorophenols, and pesticides (Bumpus et al. 1985). In addition, fungi have advantages over bacteria such as fungal hyphae that can penetrate contaminated soil to reach the PAHs that have 